\title{
Szaleństwo i wiara Elżbiety Belenson. Próba przekładu
}

\author{
Jarosław Młynarczyk \\ Uniwersytet w Białymstoku, Instytut Filozofii, Polska \\ ORCID: 0000-0003-1801-397X \\ jarek-mlynarczyk@wp.pl \\ J. Młynarczyk, The madness and faith by Elizabeth Belenson. Translation attempt, Elpis, 22 2020: 135-138.

\begin{abstract}
The short text of Elisabeth Belenson can be understood as an insight into the nature of the human soul. The author describes madness as a special state of the soul and the most mysterious and dangerous way of moving towards God. It is also a grasp of the mentality and way of thinking of philosophers and writers of post-revolutionary Russian emigration, in which in a strange relationship there is Greek mythology, criticism of positivism and faith in God's Mercy.
\end{abstract} \\ Streszczenie: Krótki tekst Elżbiety Belenson może być rozumiany jako wgląd w naturę duszy ludzkiej. Autorka opisuje szaleństwo \\ jako szczególny stan duszy i najbardziej tajemniczy oraz niebezpieczny sposób zmierzania w stronę Boga. Jest to także uchwycenie \\ mentalności i sposobu myślenia filozofów i pisarzy porewolucyjnej emigracji rosyjskiej, w którym w przedziwnym związku istnieje \\ grecka mitologia, krytyka pozytywizmu oraz wiara w Miłosierdzie Boże.
}

Keywords: Russian philosophy, faith, madness, Put, Belenson

Słowa kluczowe: filozofia rosyjska, wiara, szaleństwo, Put, Belenson

Artykuł stanowi próbę przekładu tekstu „Szaleństwo i wiara” Eli Enson ${ }^{1}$ opublikowanego w czasopiśmie „Put” w roku 1926 (Belenson 1926, s. 137-138). Autorski przekład z jęz. rosyjskiego został poddany krótkiej analizie w końcowej części artykułu.

\section{„Szaleństwo i wiara" Elżbiety Belenson - przekład tekstu ${ }^{2}$}

Szaleństwo jest pojmowane przez człowieka wierzącego jako inne pojęcie niż to, jakim jawi się ono psychiatrze. Kabała nazywa je „wymianą świeczników”3. Przede wszystkim określenie to odnosi się do tego rodzaju choroby, która w sposób tajemniczy nawiedza i opuszcza ciało. Nie jest ona efektem procesów organicznych, lecz wiecznych praw duszy. Różnica dusz i wyją̨tkowość natury każdej z nich determinuje przebieg choroby, zasadniczo religijnej i wyrastającej z rozdarcia człowieka między dobrem a złem, między Bogiem a grzesznością.

W tym rozumieniu doświadcza się dysonansu niewierzącego/niedowierzającego umysłu i duszy przepełnionej świadomością winy - mistyczna tragedia duszy - który jest nie tylko wizją w ukrytych głębiach świata duchowego, ale żywą rzeczywistością. Umysł jest rozdarty i w swojej naj-

\footnotetext{
Pod tym pseudonimem ukrywała się Elżbieta Belenson (Елизавета Беленсон), dziennikarka i tłumaczka Bierdiajewa na j. francuski. Była współorganizatorką paryskiego Centrum Judaistyczno-chrześcijańskiego (ros. Иудаистско-христианский центр) przy czasopiśmie „Путь”, w którym to kilkukrotnie publikowała swoje artykuły. Za: Krotov, 2019.

2 Oryginalne przypisy autorki zostały oznaczone czcionką pogrubioną i kursywą.

3 To przedziwnie usytuowane zdanie wskazuje na znajomość tradycji mistycyzmu żydowskiego.
}

wyższej strukturze przeniesiony w sferę życia duchowego, podczas gdy przeznaczeniem duszy jest poświęcenie się podążaniu ścieżką cierpienia i zadośćuczynienia. Ostatecznie - wiara stała się poznaniem.

Nie zaprzeczając klinicznemu obrazowi choroby, pragnę wskazać na świat poza nim, najgłębiej skrywany, niepodlegający racjonalistycznemu badaniu i w najmniejszy sposób dający się wytłumaczyć. Świadomość zwyczajnego człowieka, określona poprzez z góry nakreślony porządek, postępuje w zwykły sposób. Zdarza się jednak, że niewidzialna ręka zmienia układ ogników wskazujących ścieżkę, nie gasząc ich - co narusza poprzedni porządek i sprawia, że naruszone jest także tak zwane normalne życie - powstaje życie inne: „Szaleństwo”. Umysł upada w otchłań, nie pojmując zdrowszego sensu życia. Dotychczas uśpiona moc nowej świadomości uwalnia się ze swych więzów; dusza zrzuca ciasne kajdany i bliska przełomu, rozpoczyna swoje wzlatywanie ku światu nierealnemu, bliskiemu wyższej rzeczywistości.

Szaleństwo jest straszną katastrofą, straszliwie gwałtownym wstrząsem całego jestestwa, podobne trzęsieniu ziemi, z głębin wybuchającemu płomieniem i ciemną lawą niosącemu zagładę powierzchni. Sama jednak choroba jest jedynie przejawem pierwotnego i znaczącego wydarzenia: duchowego buntu, wulkanicznego wybuchu świata wewnętrznego. Niedoskonałe naczynie musi zostać rozbite, ażeby nową, rozszerzoną objętością mogło przyjąć i pomieścić o wiele więcej treści. W imię natury doskonalszej obalaną jest niższa, niedoskonała natura. Wszystko, co ograniczone, wszystko, co martwe i rozkładające się ściera i zmywa się w ognistym potoku wiecznych boleści. W męczeńskim bólu rodzi się nowy świat. Nie tylko w drodze do Damaszku Pan objawia się czło- 
wiekowi. I w murach szpitala psychiatrycznego skrywa się błogosławiony betlejemski żłóbek. W płomieniu cierniowym schorzała dusza pojmuje prawo boskie, ażeby po swoim zbawieniu [przez Boga], pokłonić się przed cudem niebiańskiej miłości.

Być może i w tym zawiera się metafizyczny sens podobnego schorzenia. W odkupieńczym cierpieniu natomiast wyraża się jego sens religijny. Przechodząc przez wszystkie kręgi piekła dusza, krwią swoją spłaca należność ${ }^{4}$ za grzechy i za miłość [Bożą $]^{5} \mathrm{~W}$ przyszłości. Zatem choroba jawi się jako obraz najsilniejszego doświadczenia religijnego: objawieniem świata niewidzialnego i oddaniem się tajemnicom życia duchowego: śmierci ${ }^{6}$ i zmartwychwstaniu.

I wcześniej człowiek żył w jakimś niejasnym przeczuciu; wszystko, co widoczne zdawało mu się być nieprawidłowe - ludzie jawili się mu jako marionetki poruszane sztucznymi nićmi. W sposób nieodparty rosło w nim wrażenie ukrytego sensu wszystkiego, co się działo; wolniej płynęła krew w żyłach, powstawały prorocze sny, rozbłyskiwały momenty oświecenia.

Wtem, nagle, kurtyna ${ }^{7}$ się uniosła - rozpoczęła się boska komedia ${ }^{8}$ ! W tej samej chwili nić łącząca duszę ze światem ją otaczającym urywa się - nikt nie posiada większej wiedzy o tym, co wydarza się w tej duszy - kontakt jest nie możliwy, nie ma [wspólnych] słów - między światem a duszą otwarła się [bezdenna] otchłań.

Duch człowieka, samotny i wyobcowany, wstępuje na trudną oraz niebezpieczną ścieżkę swojej wielkości, [krocząc] poprzez labirynt przeobrażania się. Zuchwałą i bez-

\footnotetext{
4 W oryginale: „платить дань”. Jest to również obecnie używany związek frazeologiczny, który można oddać po polsku jako „składać hołd”. Nie jestem jednak przekonany do jego użycia. Wydaje się, że E. Belenson powiada, że jest to relacja wiązana - bez grzechu nie może uaktywnić się Miłosierdzie Boga, Jego miłość. Dopiero kiedy jesteśmy winowajcą, Bóg może odpuścić nam naszą winę. [,.(..) ostawi nam dothi nasza jakoże i my ostawiajem dolżnikom naszym; (...)"] Dopiero jeśli jesteśmy dłużnikami, możemy próbować spłacać dług, mimo że nigdy nie będziemy w stanie tego zrobić.

Miłosierdzie Boże.

6 Pomimo że autorka wyraźnie używa w swoim tekście słowa „умираніе” i niesie ono ze sobą nieco inne znaczenie niż znajomo brzmiące słowo „смерть”, postanowiłem przełożyć je w duchu chrześcijańskiej Tradycji. Zwykło się bowiem wiązać słowo „śmierć” ze słowem „zmartwychwstanie", zapewne posługując się przekładem słów świętego Pawła zawartych w Pierwszym Liście do Koryntian - „Ponieważ bowiem przez człowieka [przyszła] śmierć, przez człowieka też [dokona się] zmartwychwstanie.” (1 Kor 15, 21)

$\mathrm{Z}$ powodu wielowymiarowości tekstu trudno orzec czy chodzi o „kurtynę” czy o „zasłonę”, oba bowiem słowa oddają rosyjski wyraz „занавъсъ”. Jeśli przyjmiemy, że Belenson korzysta ze znajomości tradycji biblijnej, może jej chodzić „Zasłonę przybytku”.

Jeśliby jednak pozostać wiernym słowu „zasłona” równie dobrze może chodzić jej o schopenhauerowska „Zasłonę mai”. Pisarze i myśliciele rosyjscy, m.in. M. Dobrolubow i M. Czernyszewski, czytają i komentują A. Schopenhauera już w latach 60 XIX wieku. Tak więc zasadnym jest przypuszczenie, że wykształcona Rosjanka u progu lat 30 minionego stulecia zna tẹ idee.

O recepcji Schopenhauera w Rosji zob. np. (Walicki, 2005), (Kacprzak, 2013).

8 Po raz kolejny, po podróży duszy po kręgach piekielnych odniesienie - i to wprost - do Boskiej komedii Dantego.
}

owocną próbą zdaje się być chęć opisania tego nierealnego świata realnych cierpień ${ }^{9}$.

Samotna dusza pozbawiona wybawiającego kłębka [nici] Ariadny ${ }^{10} \mathrm{i}$ wsparcia światłego Wergiliusza ${ }^{11}$ jest zagubiona $\mathrm{w}$ przestrzeniach świata, jakoby odtrącona przez Boga i wszechświat, jakoby skazana na ciemność i diabła. Zniszczona i do granic upokorzona, pełza ona na ziemi, cierpiąc katusze i będąc męczoną wszelkimi torturami piekła, prześladowana przez Furie, przez siebie i innych wydana na pohańbienie, lecz nie ma śmierci i nie ma końca!

Podczas przeżywania tego gorączkowego biegu nie ma chwili wytchnienia, brak postoju - czas przestat istnieć - ponad wszelką konsekwencję, pośród męczeństwa w niewytłumaczalny sposób duszę przejmuje dreszcz wobec bliskości Bóstwa. W obliczu swej winy, wyjawionej w trakcie mimowolnej spowiedzi, drży ona przed wizją niebiańskiego piękna i harmonii. Zanurzona w wieczności, przestała on być, stając się jedynie widzem, mimo że jej męki nie ustają; dusza w sposób nieświadomy nasiąka poznaniem. Wszechświat rozbrzmiewa dionizyjskim smutkiem ${ }^{12}$, wszystko, co powstaje, towarzyszy rytmowi monotonnie ekstatycznego hymnu, wypełniającego duszę. Świat stał się muzyką. Przeniesiona w mroki przeszłości, dusza doświadcza początku wieków i narodzin mitu. Święta symbolika, głęboka więź, trzewia wieków odsłaniają się duchowemu widzeniu - starożytne wizje, mitologiczna tożsamość ucieleśnia się ponownie. Podobna kameleonowi ${ }^{13}$, dusza przelatuje przez łańcuch przemian, będąc świadomą jedności wszechświata ${ }^{14}$. Język zwierząt i bez słów jest zrozumiały. Znużony koci wzrok opowiada jej

\section{W sposób najbardziej znaczacy i glęboki o podobnym stanie ducha} wypowiadali się jasnowidz, E. Swedenborg oraz św. Katarzyna z Genui. ${ }_{10}$ Autorka przywołuje grecki mit o Ariadnie i Tezeuszu. To dzięki ofiarowanej przez nią nici heros powrócił z Labiryntu Minotaura.

Może to być jakoś eksploatowana idea wiecznego powrotu, zaczerpnięta $\mathrm{z}$ filozofii F. Nietzschego. Tak jak Ariadna występuje przeciw siłom przyrody i życia - przeciw Minotaurowi, pod postacią którego skrywa się bóstwo witalności, Dionizos - chociaż jest im podległa (Rolka, 2014, s. 106-113), tak i dusza będąca w świecie nie należy do tego świata. Wszelkie jej działania skierowane są ku uczestnictwu w życiu innym niż to, które spętane jest władzą Natury. Pragnie więc ona powrotu na drogę Prawdy, chociaż z niej zbacza i pragnie powrotu do Boga, chociaż od niego odchodzi.

${ }_{11} \mathrm{Tu}$ z kolei nawiązuje do Eneidy rzymskiego autora Wergiliusza. W Księdze VI tegoż poematu Eneasz, jego główny bohater, wstępuje z wieszczką Sybillą do Hadesu. Spotyka tam szereg dusz - między innymi: ojca, kobiety która była w nim zakochana czy czekających na wcielenie potomków (np. Romulusa, Cezara, Oktawiana Augusta).

12 Odwołanie do dychotomii dionizyjskiej prawdy i apollińskiego pozoru, opisanej w książce F. Nietzschego Narodziny tragedii, czyli hellenizm i pesymizm. Więcej o niej w: Rolka, 2014, s. 17-42, 47-48.

W oryginale zdanie to brzmi: „Хамелеономъ проносится душа сквозь цьпь превращеній, сознавая единство вселенной.”. Nie jest jasne czy autorce chodzi o zwierzę, a zatem o symbol ciągłych przemian, czy Chamaeleon, Kameleona, tj. gwiazdozbiór nieba południowego. W związku z użyciem słowa „проноситься”, co znaczy po polsku „przelatywać”, „fruwać”, „latać”, oraz zwróceniem uwagi na jedność wszechświata (gwiazdy traktowane są w wielu tradycjach jako odwieczne), wydaje się być zasadnym zwrócenie uwagi na ten homonimiczny charakter słowa „kameleon”. Możliwe jednak, że jest to świadoma gra słowem, ponieważ zdanie to otwiera nową myśl - o przenoszeniu mądrości wieków, jedności wszechświata, ideał Prawzorca przez zwierzęta.

14 Tu prawdopodobnie autorka odnosi się do koncepcji Wszechjedności Włodzimierza Sołowjowa. 
o [minionych] stuleciach. Łza współczucia w ślepiach psa dotyka ją bardziej niż ludzka litość. Męczeństwo konia, najbardziej samotnego spośród ziemskich stworzeń, napełnia ją palącym poczuciem winy i w wyraźny sposób objawia się jej zwierzęce Bóstwo, jakim widziały go starożytne ludy. A przez to wszystko wije się krwistoczerwoną wstęgą męka... Miłość, rozpacz i śmierć - i brak śmierci - i dziki krzyk o końcu...!

Jednak czas się wypełnił ${ }^{15}$. Kurtyna opada. Czary zniknęły. W trzeźwym świetle ${ }^{16}$ naszego realnego życia staje człowiek uzdrowiony, wyzwolony, jaśniejący i odnowiony, w swej krwi obmyty i oczyszczony. Lecz... Czy nie jest tak, że mu się to jedynie zdaje? Nigdy się do niego nie uśmiechaj, ponieważ niemożliwym jest zapomnieć.

Odtąd doświadczają oni ukrytego sensu Pisma Świętego - otwierają się zamknięte przed rozumem wrota, a oni podobni Łazarzowi, wzbudzonemu ${ }^{17}$ ku nowemu życiu, dusza zmartwychwstaje ku światłu. Bezmiar boleści, ukryta miłość, wysokie i nieskończone - wszystko, wszystko to spływa w jeden potok cierpienia, rozrywając duszę i ciało, by na końcu znaleźć swe ujście w ekstatycznym ${ }^{18}$ geście modlitwy ${ }^{19}$.

W Ewangelii opisana jest historia chorego, który nie inaczej jak tylko przez dach, mógł dotrzeć do Jezusa ${ }^{20}$, ponieważ inne ścieżki i przejścia, były już zajęte przez szczęśliwszych i zdrowszych. Musiano więc rozebrać „dach” i podźwignąć tam chorego. Czyż nie to samo ma miejsce w religijnym szaleństwie, najbardziej tajemniczym i niebezpiecznym kroku w stronę Boga?

Eli Elson

\section{Krótka analiza artykułu Elżbiety Belenson}

Tekst Elżbiety Belenson zdumiewa od chwili pierwszego z nim zetknięcia. Krótki, najkrótszy w całym drugim numerze Puti, mieni się całą gamą kontekstów i znaczeń,

\footnotetext{
15 Mk 1, 15, „Czas się wypełnił i bliskie jest królestwo Boże. Nawracajcie się i wierzcie w Ewangelię!"”.

16 Jedna z kategorii filozofii Kartezjusza. Według niego to, co jest proste, jest jasne i zarazem wyraźne (clair et distinct). Tak też chce on widzieć człowieka (automatyzm). Zob. tegoż, Rozprawa o metodzie.

Przytyk wymierzony w pozytywistyczną racjonalność, którą gromił również Sołowjow.

17 Chociaż mowa jest o wskrzeszeniu Łazarza, które jest opisane w Ewangelii św. Jana (J 11), w tekście E. Belenson pada słowo „разбуженная”, co należałoby oddać jako „wzbudzonemu” i odwołuje się bezpośrednio do fragmentu „To powiedział, a następnie rzekł do nich: «Łazarz, przyjaciel nasz, zasnął, lecz idę, aby go obudzić»». Uczniowie rzekli do Niego: «Panie, jeżeli zasnął, to wyzdrowieje». Jezus jednak mówił o jego śmierci, a im się wydawało, że mówi o zwyczajnym śnie. Wtedy Jezus powiedział im otwarcie: «Łazarz umarł, ale raduję się, że Mnie tam nie było, ze względu na was, abyście uwierzyli. Lecz chodźmy do niego!»” (J 11, 11-15).

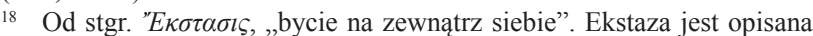
także przez św. Pawła (2 Kor 2, 1-4).

19 Rzecz dotyczy, oczywiście, wylącznie subiektywnego, a nie ogólnego doświadczenia. Naturalnie nie stwierdza tu się żadnej choroby, lecz podejmuje się jedynie próbę rozjaśnienia [problemu] najcięższej spośród wszystkich chorób w znaczeniu duchowym.

20 Łk 5,17-26.
}

które niejednoznaczne i nieodkryte, w każdej chwili zdolne są ulecieć mniej uważnemu czytelnikowi.

Trudno jednoznacznie orzec czym ten artykuł jest. Czy jest to ostrze krytyki wymierzone w krzewicieli pozytywistycznej racjonalności, która chciałaby doskonałej klasyfikacji wszystkiego co ludzkie? Być może. Czy jest to prezentacja sposobu myślenia filozofów i pisarzy uciekających z Rosji po Rewolucji 1917 roku? Niewykluczone, chociaż nie jest to, jak mnie się zdaje, zamiar autorki. A może jest to głębokie studium natury duszy ludzkiej? Wydaje się, że przede wszystkim.

Dokonując zatem analizy tekstu na kilku płaszczyznach zetkniemy się z równoczesnym wykorzystaniem greckiej mitologii, Eneidy rzymskiego klasyka - Wergiliusza, Dantego i jego Boskiej komedii, intuicji zapożyczonych jak się zdaje z tradycji filozofii niemieckiej - Schopenhauera i Nietzschego - czy bezpośrednich odwołań do tekstów ewangelicznych. Belenson tworząc tak wielobarwny kolarz przeprowadza nas i duszę, jak ją rozumie, poprzez swoistą drogę krzyżową. Nie jest to przyjemny spacer po parku, ani przejażdżka pociągiem. Jest to wąska ścieżka pełna niebezpieczeństw i niewygód. To wielka pielgrzymka umęczonego jestestwa, zrywającego ze światem doczesnym a kierującego się wprost w objęcia Boskiej Miłości.

Męczennik oddaje swoje życie za wiarę w Chrystusa, natomiast człowiek zwyczajny, jakbyśmy go określili zdrowy psychicznie, chroni swoje życie za wszelką cenę. Nie będzie on chodzić nago i boso wobec innych (Iz 20,3) i nie przyjmie na swoją szyję jarzma (Jr 27,2), gdyż nie widzi żadnej potrzeby w dodatkowym umęczeniu siebie. Aby uczynić to wszystko trzeba być szaleńcem. Czyny męczeńskie są zatem szaleństwem w oczach tego świata.

Taki szaleniec Chrystusowy, jurodiwyj, w tradycji rosyjskiej doczekał się zaszczytnego miejsca jako jeden z ludowych wzorców świętości. Wystarczy spojrzeć na obrazy P. Swedomskiego czy W. Surikowa, aby dostrzec widome oznaki odbiegania tych ludzi od pewnych, społecznie akceptowanych norm zachowania. Siedzą oni na śniegu w łachmanach błogosławiąc wszystko wokół. Innym ludziom trudno jest pojąć cel i genezę takich zachowań, lecz wystarczy zasięgnąć rady Św. Apostoła Pawła, aby to zrozumieć. Powiada on (1 Kor 1, 21-25): „Skoro bowiem świat przez mądrość nie poznał Boga w mądrości Bożej, spodobało się Bogu przez głupstwo głoszenia słowa zbawić wierzących. Tak więc, gdy Żydzi żądają znaków, a Grecy szukają mądrości, my głosimy Chrystusa ukrzyżowanego, który jest zgorszeniem dla Żydów, a głupstwem dla pogan, dla tych zaś, którzy są powołani, tak spośród Żydów, jak i spośród Greków, Chrystusem, mocą Bożą i mądrością Bożą. To bowiem, co jest głupstwem u Boga, przewyższa mądrością ludzi, a co jest słabe u Boga, przewyższa mocą ludzi.”.

Ta apoteoza jurodiwych jest przez autorkę przesuwana również w kierunku szpitali psychiatrycznych, w których Bóg również może objawiać swoją obecność. Wszakże każdy człowiek - bez wyjątków - powołany jest do poszukiwania Go. Czasem można Stwórcę dostrzec w uzmysłowieniu sobie Jego wielkiego, odwiecznego planu, który jest realizowanym przez Naturę prawem. Wgląd ten 
przychodzi nagle - podczas obserwacji kota czy gwiazd. Innym razem jest On obecny w cierpieniu człowieka lub zwierzęcia. To dlatego ból jest nie tylko męką, lecz również możliwością spotkania Go. Napełnia więc człowieka - stworzenie - lęk związany nie tylko z cierpieniem, ale i nieuchronnym spotkaniem $\mathrm{z}$ nim $(\mathrm{Sdz} 13,22)$.
Jedni, szczęśliwsi i zdrowsi, jak pisze Belenson, spotykają Boga, na ścieżkach i traktach prostszych - którymi porusza się wielu. Inni zmierzają do niego w sposób okupiony wieloma problemami, między innymi na drodze szaleństwa. Oby zarówno ci pierwsi, jak i ci drudzy Go w końcu poznali.

\section{Bibliografia}

Biblia Tysiaclecia. Pismo Święte Starego i Nowego Testamentu. (2003). Poznań: Wydawnictwo Pallottinum.

Belenson, (1926). Belenson, E. (Èli Èl'son). (1926) Bezumie i vera. Put'. Organ" Russkoj Religioznoj Mysli. Berdâev, N. A. (red.)1926 2, 137-138 [Беленсон, Е. (Эли Эльсон). (1926) Безумие и вера. Путь. Органъ Русской Религіозной Мысли. Бердяев, Н. А. (red.) 1926 2, 137-138].

Kacprzak, M. C. (2013). Rosyjski nihilizm lat sześćdziesiatych XIX wieku (Czernyszewski, Dobrolubow, Psiarew) i jego krytyczna recepcja u Dostojewskiego w ,Drogowskazach”. [online] https://depotuw.ceon.pl/bitstream/handle/item/321/ Ros.\%20nihilizm.pdf?sequence=2/, [16.10.2019].
Rolka, M. (2014). Hermeneutyka mitu dionizyjskiego w filozofii Fryderyka Nietzschego. Katowice: Wydawnictwo Uniwersytetu Śląskiego.

Walicki, A. (2005). Zarys myśli rosyjskiej. Od Oświecenia do renesansu religijno-filozoficznego. Kraków: Wydawnictwo Uniwersytetu Jagiellońskiego.

Wergiliusz. Eneida. [online] https://wolnelektury.pl/media/book/ pdf/wergiliusz-eneida.pdf/, [16.10.2019].

Krotov, Y. Bogochelovecheskayaistoriya. Vera. Vspomogatel'nyye materialy. [Кротов, Я. Богочеловеческая история. Вера. Вспомогательные материаль.]. [online] http://yakov.works/spravki/1_history_bio/19_1890/1887_ Belenson.htm/, [09.10.2019].

Rozmiar artykułu: 0,5 arkusza wydawniczego 